\title{
Effect of Realistic Mathematical Approaches against Results Learning Mathematics and Student Learning Motivation SDN 102119 Nagaraja Serdang Bedagai
}

\author{
Maria Melfa Simanjuntak ${ }^{1}$, Hasratuddin $^{2}$, Zulkifli Matondang $^{3}$ \\ ${ }^{1}$ Postgraduate Program of Basic Education, Universitas Negeri Medan, Indonesia \\ 2,3Postgraduate of Basic Education, Universitas Negeri Medan, Indonesia \\ Email: mariasmnjtk7@gmail.com
}

\begin{abstract}
Mathematics learning outcomes obtained by students at least describe the achievement of learning objectives to be achieved. But the learning outcomes of students at SD Negeri 102119 Nagaraja are still relatively low with a low level of student motivation so that it influences the teaching and learning process. With one alternative that can help using the Realistic Mathematical Approach (PMR) can improve student learning outcomes and motivation to learn mathematics. Therefore, this study aims to examine the Effect of Realistic Mathematical Approaches on Learning Outcomes of Mathematics; Effect of Realistic Mathematical Approaches on Student Learning Motivation; and Great influence of learning approaches on student learning outcomes in mathematics and student motivation. This research is a quasi-experimental research. The population in this study were all fourth grade students of SD Negeri 102119 Nagaraja Serdang Bedagai, totaling 54 students. The instrument used consisted of a test of learning outcomes and a motivation questionnaire. Data were analyzed with the Simple Regression Analysis Test. Based on the results of the analysis the results of the study are obtained that the Realistic Mathematics Approach gives an effect on the mathematics learning outcomes of fourth grade students of SD Negeri 102119 Nagaraja Serdang Bedagai because the value of Sig. equal to 0,00 <0,05 with $t$ count 7,158> t table 2,064; The Realistic Mathematics Approach does not have an effect on student motivation because the value of Sig. of $0.84>0.05$ with $t$ count $0.193<t$ table 2.064; and The magnitude of the effect of the learning approach on mathematics learning outcomes $68.1 \%$ and the effect of the learning approach on learning motivation $0.2 \%$ while the remaining $31.7 \%$ is influenced by factors other than the learning approach.
\end{abstract}

Keywords: realistic mathematics approach; mathematics learning outcomes; learning motivation

\section{Introduction}

Education is a form of community life that is dynamic and is needed by all people. Therefore, education plays an important role because education as a vehicle to improve and develop the quality of human resources (HR). In an effort to improve quality human resources, there are many factors that influence the progress of national education including students, educators, education channels, types of education, and education units. Currently the world of education is being faced with two major problems, namely the low quality of education and learning systems in schools that are less effective.

In the learning process, a teacher's self-skills so that students easily understand the material provided by the teacher is very important. Teachers are required to innovate and be creative in implementing learning, so that student learning outcomes are satisfying and in accordance with the expected learning objectives. One of the most complained subjects is mathematics. 
Teacher's expertise in carrying out educational tasks is obtained after taking certain teacher education that is not possessed by other professions. There are several roles teachers can play as educators, including: (a) As a professional worker with the function of teaching, guiding and training. (b) Humanitarian workers with the function can realize all their human capabilities. (c) As a benefit officer with the function of teaching and educating the public to be good citizens (Saragih and Mardianto, 2019).

Mathematics learning tends to make students feel bored, uninterested, and less creative, less developed abilities, lack of student motivation and the saddest results and achievements of student mathematics learning to date have not been satisfactory. According to Darhim (2004: 4) that mathematical dislikes by students might be influenced by material factors or the learning process.

Meanwhile, in learning activities, teachers still lack attention to students' thinking abilities and learning interests. The teacher has not fully tried to arouse students' motivation to learn mathematics, and therefore there is one renewal effort to improve mathematics learning can be done with one alternative approach that can help teachers so that students are more active in class and are very compatible with mathematics learning, namely a realistic approach that refers in Realistic Mathematics Education (RME). The importance of using this approach in mathematics learning according to Wijaya (2012: 20) is "a knowledge will be meaningful for students if the learning process is carried out in a context or learning using realistic problems".

A realistic approach involves activities and all elements in daily life so that mathematics learning is more meaningful, the feedback between the teacher and students will be well established, the teacher becomes a facilitator and students become active. There are many factors both inside and outside that can influence student success in learning. One factor that can support student learning outcomes is motivation.

The process of learning mathematics that often occurs in the field is still emphasized on memorizing abstract mathematical formulas so that it can reduce student motivation to learn mathematics. In learning activities, motivation as a driving force in students that cause learning activities with a variety of feelings or circumstances, so that the desired goals by students can be achieved properly. Therefore motivation has an important impact on learning outcomes. Learning motivation can be developed, improved, and maintained by external conditions, such as the presentation of lessons by teachers with varied media, appropriate methods, appropriate approaches, and so on.

According to Rini, E (2016: 20): Mathematics learning requires a good and correct understanding of concepts and is supported by the provision of learning motivation so that students can accept and understand everything related to the material explained by the teacher. Meanwhile according to Rawa and Bhoke (2017: 22) states that: sometimes motivation is often forgotten in learning practices. Many teachers still do not provide motivation at the beginning of the lesson by not giving examples of the application of mathematics in everyday life.

Suherman, et al (2003: 236) for this reason, so that students are more motivated and earnest in learning mathematics, the teacher should:

a. Show how useful mathematics is in life through examples of the application of mathematics that are relevant to the daily world of students.

b. Using techniques, methods, and approaches to learning mathematics that are appropriate in accordance with the characteristics of the topics presented. 
c. Utilizing various techniques, methods, and approaches in learning mathematics so as not to be monotonous.

Therefore, one alternative that can be used is a realistic mathematical approach that can increase learning motivation and the achievement of learning objectives with good mathematical learning outcomes. The objectives of this study are: 1) to analyze the effect of realistic mathematical approaches on mathematics learning outcomes of fourth grade students of SD Negeri 102119 Nagaraja. 2) to analyze the effect of a realistic mathematical approach to the learning motivation of fourth grade students of SD Negeri 102119 Nagaraja. 3) To analyze the magnitude of the effect of the learning approach on mathematics learning outcomes and learning motivation of fourth grade students at SD Negeri 102119 Nagaraja.

\section{Review of Literatures}

\subsection{Realistic Mathematical Approach}

Education is part of the intellectual life of the nation as mandated in the 1945 Constitution, likewise in the Law of the Republic of Indonesia No. 20 of 2003 concerning the National Education System which states that the goal of national education is to educate the life of the nation, to develop the potential of students so that they can become people who have faith and are devoted to God Almighty, noble, capable, creative, independent and become citizens of a democratic and responsible country. To that end, the government has sought to develop the education sector in a planned, directed, and gradual manner and integrated with the overall development of the nation's life, both economic, social, cultural, scientific and technological (Rasien, 2020).

Student learning processes will occur when the knowledge being learned is meaningful to students. A knowledge will be more meaningful if the learning process involves realistic in a context. The learning process is a learning process with a realistic mathematical approach. Learning by using a realistic mathematical approach, designed starting from the problems that exist around students and based on the knowledge they have, so that it is expected to improve students 'mathematical understanding, directing students to have mathematical understanding abilities and opening students' insights into the real world.

According to Wijaya (2012: 21) explains that "in realistic mathematics education, realistic problems are used as a foundation in building mathematical concepts or also referred to as a source for learning". Meanwhile according to Lestari (2015: 3) argues that "the application of the RME approach in the learning process will be more fun and meaningful for students because it involves students actively and builds their understanding independently through the presentation of problems related to students' daily lives".

Soedjadi (2001: 2) argues that "learning mathematics with a realistic approach is basically the use of reality and the environment understood by students to facilitate the process of learning mathematics so as to achieve the goals of mathematics education better than in the past". Tung (2015: 288) "Realistic Mathematics Education (RME) is a learning theory in mathematics education that is based on the idea that mathematics is a human activity and must be clearly linked to the context of students' daily lives".

According to Barnes (2004: 54) states: Realistic Mathematic Education (RME) originated from the view of Hans Freundenthal who stated mathematics as human activity. Two important views of Freudenthal (in Novitasari, 2007: 6) about Realistic Mathematic Education (RME) are: 
a. Mathematics as human activity, so students must be given the opportunity to learn to do mathematical activities on all topics in mathematics,

b. Mathematics must be connected to reality, so mathematics must be close to students and must be linked to everyday life situations.

Based on some of the opinions above, it can be concluded that the realistic mathematics approach is a learning theory that links mathematics with the real or concrete world that is in the minds of students so that in the process of learning mathematics can achieve better goals.

According to Gravemeijer (1994: 90), there are three key principles in RME, namely: 1) Guided Reinvention and Progressive Mathematizing. 2) Didactical Phenomenology. and 3) Self Developed Models. Meanwhile, according to Gravemeijer (in Zulkardi, 2010: 4) the mathematics learning process based on RME has five characteristics, namely: 1) using contextual problems 2) using models 3) using student contributions 4) interactivity 5) related to other topics. According to Suharta (2002: 644) the principle of RME is to use context, realworld, models, production and construction of students, interactive and interrelated. The syntax of a realistic mathematical approach, namely: 1) Understanding contextual problems. 2) Explain contextual problems. 3) Resolve contextual problems. 4) Comparing and discussing answers and 5) Concluding.

Theories that support the application of this realistic mathematical approach are supported by several experts to enable learning to be achieved. According Hudojo (1998: 47) "according to cognitive learning theory, learning and thinking is basically doing a change in cognitive structure". Specifically, relating to mathematics learning, Piaget (in Suparno, 2001: 149-150) "suggests that mathematics learning emphasizes more on activities, experiences, and the use of active methods, as well as starting from the concrete and slowly moving towards abstracts. In addition, Piaget argues that a genuine understanding of an understanding or a theory demands a discovery of that theory."

Vygotsky's theory (in Slavin, 1997: 47-48) "emphasizes the sociocultural nature of learning, that is, students learn to handle tasks learned through interactions with adults or peers". It can be seen that the realistic approach is in line with Vygotsky's theory, because in realistic learning students are given the opportunity to build and rediscover mathematical ideas and concepts with teacher guidance and emphasize the need for continuous interaction between students with each other, also between students with teachers and students with learning tools so that each student gets a positive benefit from the interaction.

According to Bruner (in Hudojo, 1998: 56) argues that "learning mathematics is learning about mathematical concepts and structures contained in the material being studied and looking for relationships between mathematical concepts and structures". Bruner divides the stages of children's learning through enactive, iconic, and symbolic stages. The Realistic Mathematical Approach is in accordance with the theory proposed by Bruner, because at the beginning of learning it is possible for students to manipulate objects related to contextual problems given by the teacher. Then in the vertical mathematical process students manipulate symbols.

According to Ausubel (in Orton, 1992: 155) "meaningful learning is a process when a new knowledge is absorbed by connecting with aspects of the individual's existing knowledge structure and relevant. If there are no relevant concepts that can be linked or linked then the new knowledge is only learned by memorizing ". In learning mathematics with a Realistic 
Mathematical Approach, students "discover" their knowledge of contextual problems and relate that knowledge to the concept or way to be built.

\subsection{Learning Outcomes}

Learning outcomes can be achieved from student achievement in the process of teaching and learning activities by bringing a change and the formation of a person's behavior. Learning outcomes are often used as benchmarks to find out how far someone masters the material that has been taught. Although through the same learning process, learning outcomes achieved by someone can not be the same. According to Ahmad Susanto (2013: 5): "Learning outcomes are changes that occur in students, both concerning cognitive, affective, and psychomotor aspects as a result of learning activities. Put simply, what is meant by student learning outcomes is the ability acquired by children after going through learning activities ". Sudjana (in Jihad and Haris 2013: 15) argues, "Learning outcomes are abilities students possess after they have received their learning experience".

Suprijono (2011: 5) states that: Learning outcomes are changes in behavior as a whole not just one aspect of humanity's potential, that is, learning outcomes categorized by education experts as mentioned above are not seen separately but are comprehensive. Based on some of the opinions above, it can be concluded the learning outcome is the achievement of learning goals that bring about a change and the formation of a person's behavior, in an assessment process carried out by the teacher to achieve the expected learning goals.

The achievement of learning can be seen from the results of student learning, but the learning outcomes obtained by students, are influenced by several factors, both from oneself and from outside such as the environment. According to Syaiful Bahri Djamarah (2011: 175), states the factors that influence the process and learning outcomes are:

a. External Factors, namely: environment (natural and social culture), and instrumental (curriculum, programs, facilities and facilities, as well as teachers)

b. Internal Factors, namely physiological (biological and sensory conditions), and psychological (interests, intelligence, talents, motivation, and cognitive abilities).

So the factors that influence student learning outcomes there are two factors, namely factors from within students and factors that come from outside themselves the better the condition of these factors, the better student learning outcomes.

\subsection{Learning Motivation}

The term motivation is often associated with the term "motive" which is interpreted as a person's power to encourage doing an activity. By having good learning motivation, someone will choose their own learning activities. According to Mc.Donald (in Sardiman 2005) that motivation is a change in energy in a person which is marked by the emergence of "feeling" and preceded by a response to the existence of goals. Surya (2015) states that motivation is the efforts made by someone to raise or increase motives that are the driving force or dynamics of individuals in achieving goals".

Motivation is an integral part of learning. Students who have high learning motivation will usually get high learning outcomes and vice versa students who have low learning motivation will usually get low grades too. Motivation is influenced by two factors, namely internal factors and external factors of the individual or students themselves. A student's motivation to learn is certainly different from other students. Learning motivation is also influenced by the social culture of the community where students live. (Karsono 2017: 51). 
For a teacher, the purpose of motivation is to move or stimulate students so that they want and want to improve their learning achievements so that educational goals are achieved as expected and set in the school curriculum. In terms of learning, motivation can be interpreted as the overall driving force in students who give rise to, and provide direction for teaching activities, so that learning objectives can be achieved. Learning motivation can be developed, improved, and maintained by external conditions, such as the presentation of lessons by teachers with varied media, appropriate methods, real learning approaches, dynamic communication and so on. Therefore, the teacher should try as hard as possible to increase learning motivation to achieve good learning outcomes, for example by actively during learning.

Indicators of learning motivation according to Sardiman (2009: 83) as follows: a) Diligently facing the task; b) Resilient in facing difficulties; c) Showing interest in various types of problems; d) Prefer to work independently; e) Get bored easily with routine tasks; f) Can defend his opinion; g) It is not easy to give up what is believed; h) Happy to find and solve complex problems. So in outline there are two groups of indicators of motivation to motivate student learning, namely: a) Internal impulses which include desires and desires to succeed, encouragement and needs in learning, hopes and ideals of the future, and physiological factors; and b) External encouragement which includes: interesting activities in learning and a conducive learning environment.

\section{Research Methods}

The subjects in this study were all students of grade IV 102119 Nagaraja, consisting of two classes, namely IVA and IVB, totaling 54 students. The research sample was determined by total sampling of one class as an experimental class taught with the Realistic Mathematics Approach and one class as a control class being taught conventionally. The design of this study uses quasi-experimental research methods because this study wants to know the effect of certain treatments on others (Sugiono: 2011: 11). The instrument data obtained were subsequently used Simple Linear Regression analysis on SPSS 20.

\section{Discussion}

This research was conducted using Simple Linear Regression with the help of SPSS 20. The following results were obtained:

Table 1. Equation I Simple Linear Regression

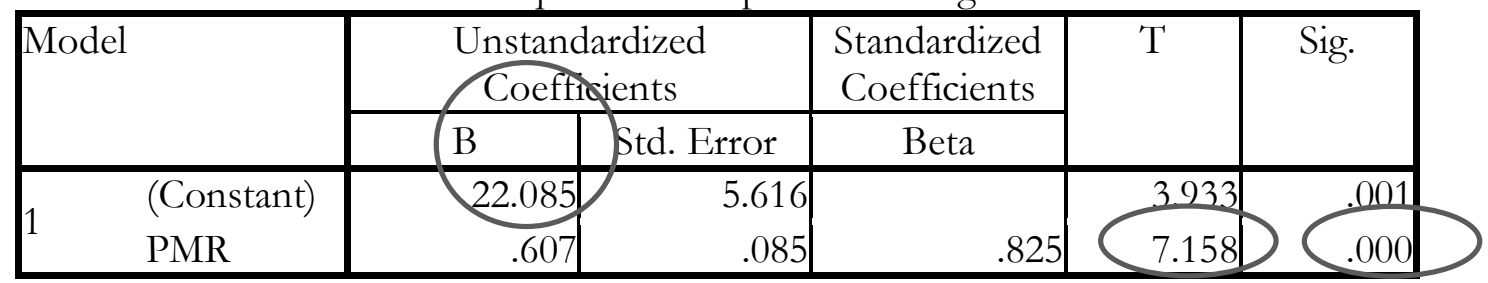

Then obtained the equation Y $1=22.085+0.607 \mathrm{X}$ that is the significance value obtained $0.00<0.05$ with t count $7.158>$ t table 2.064 .

1). There is an influence of the Realistic Mathematics Approach to the mathematics learning outcomes of fourth grade students at SD Negeri 102119 Nagaraja.

Based on the results of table 1 of the simple linear regression analysis above with the help of SPSS 20 application, it is obtained $t$ arithmetic Learning Outcomes variable $=7.158>\mathrm{t}$ 
table 2.064 while the significance value obtained is $0.00<0.05$. So it was concluded accept $\mathrm{H} 0$ and reject $\mathrm{Ha}$ so there is an influence of the use of the Realistic Mathematical Approach (PMR) on the Mathematics Learning Outcomes of Grade IV 102119 Nagaraja Elementary School students.

Table 2. Equation II Simple Linear Regression

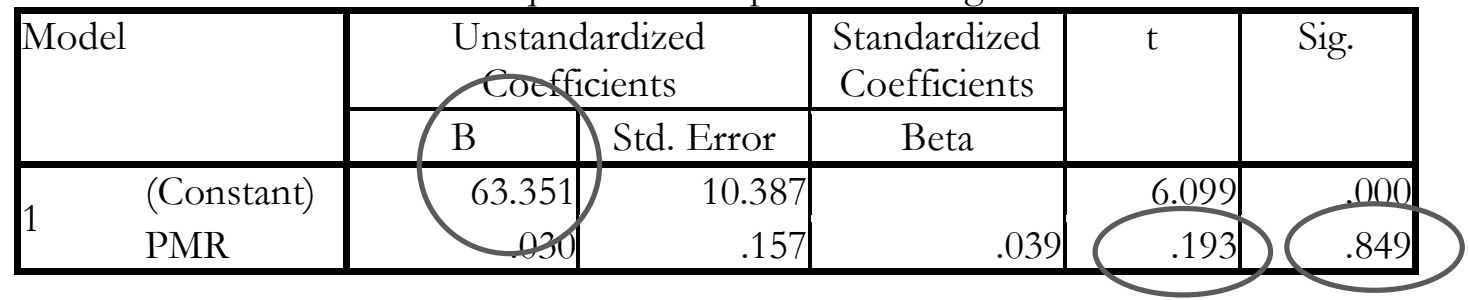

Then obtained the equation Y $2=63.335+0.030 \mathrm{X}$ ie the significance value obtained $0.84>0.05$ with $t$ count $0.193<$ t table 2.064 .

2). There is no influence of the use of the Realistic Mathematical Approach (PMR) on the motivation of students in class IV SD 102119 Nagaraja.

Based on the results of table 2 the simple linear regression analysis above with the help of SPSS 20 application obtained t count Learning Motivation variable $=0.193<\mathrm{t}$ table 2.064 while the significance value obtained was $0.84>0.05$. So it was concluded rejecting $\mathrm{H} 0$ and accepting $\mathrm{Ha}$ so there was no effect of the use of the Realistic Mathematical Approach (PMR) on the learning motivation of fourth grade students at SD Negeri 102119 Nagaraja.

Table 3. Percentage of Influence between Variables X and Y1

\begin{tabular}{|l|r|r|r|r|}
\hline Model & R & $\begin{array}{c}\text { Adjusted R } \\
\text { Square }\end{array}$ & $\begin{array}{c}\text { Std. Error of the } \\
\text { Estimate }\end{array}$ \\
\hline 1 & & .668 & 6.017 \\
\hline
\end{tabular}

Table 4. Percentage of Influence Between Variables X and Y2

\begin{tabular}{|l|r|r|r|r|}
\hline Model & $\mathrm{R}$ & R Square & $\begin{array}{c}\text { Adjusted R } \\
\text { Square }\end{array}$ & $\begin{array}{c}\text { Std. Error of the } \\
\text { Estimate }\end{array}$ \\
\hline 1 & & & -.040 & 11.130 \\
\hline
\end{tabular}

Then obtained based on table 3 the influence of the learning approach on mathematics learning outcomes of $68.1 \%$ and based on table 4 the influence of the learning approach on learning motivation of $0.2 \%$.

3). The influence of learning approaches on mathematics learning outcomes and learning motivation of fourth grade students at SD Negeri 102119 Nagaraja

So the large percentage of the effect of PMR on mathematics learning outcomes $68.1 \%$ greater than the effect of PMR on learning motivation $0.2 \%$ while the remaining $31.7 \%$ is influenced by factors other than the learning approach. These other factors can be in the form of prior knowledge, knowledge in other subjects, and experiences in daily life.

Therefore it is seen that the influence of the learning approach on student mathematics learning outcomes is much higher than the effect of the learning approach on student motivation, this is due to many factors that greatly influence the level of student motivation both from inside and outside the student making it difficult predicted by researchers. 


\section{Conclusion}

The conclusion that can be made from the results of this study is that there is the influence of a realistic mathematical approach to student mathematics learning outcomes, but there is no effect of a realistic mathematical approach to student motivation because there are many factors both from outside and within the student, while the influence of the learning approach on student mathematics learning outcomes is higher than the effect of learning approaches on student motivation. The use of realistic mathematics approach in learning has a positive impact because it connects mathematics with the real or concrete world that is in the minds of students in accordance with the experiences of daily life so that in the process of learning mathematics can achieve better goals.

\section{References}

Barnes. 2004. Realistic Mathematich Education: Elicting Alternative Mathematical Conception of Learners. African Journal of Research is SMT Education. Vol. 8(1). 55-64

Darhim. 2004. Pembelajaran Matematika Kontekstual Terhadap Hasil Belajar dan Sikap Siswa Sekolah Dasar Kelas Awal dalam Matematika. Disertasi PPs UPI Bandung. Tidak dipublikasikan.

Djamarah, S.B. 2011. Psikologi Belajar. Jakarta: Rineka Cipta

Gravemeijer, K. 1994. Developing Realistic Mathematics Education. Utrecht: Freudenthal Institute

Hudojo, H. 1998. Pembelajaran Matematika. Jakarta: Depdikbud

Jihad, A dan Abdul Haris, A. 2013. Evaluasi Pembelajaran. Yogyakarta: Multi Pressindo

Karsono. 2017. Pengaruh Penggunaan LKS Berbasis HOTS Terhadap Motivasi dan Hasil Belajar IPA Siswa SMP. Jurnal Pendidikan Matematika dan Sains. Vol.1, No. 50-57

Lestari, dan Yudhanegara, R.M. 2015. Penelitian Pendidikan Matematika. Bandung:PT. Refika Aditama.

Novitasari, I. 2007. "Realistik Mathematics Education (RME): Pendekatan Pendidikan Matematika Dalam Konsep dan Realitas" Jurnal Pemikiran Alternatif Pendidikan. Vol.12.

Orton. 1992. Learning Mathematics (Second Edition). London: Cassel

Rasien. (2020). The Effect of Blended Learning Strategy and Creative Thinking of Students on the Results of Learning Information and Communication Technology by Controlling Prior Knowledge. Budapest International Research and Critics in Linguistics and Education (BirLE) Journal. P. 879-893.

Rawa, N. R dan Bhoke, W. 2017. Pengaruh Penggunaan LKS Matematika Berbentuk Komik Terhadap Motivasi Belajar Siswa Sekolah Dasar. Jurnal Math Educator Nusantara (JMEN). Vol.3, No.1

Rini, E. 2016. Pemahaman Konsep dan Motivasi Belajar Matematika Siswa Kelas X Madrasah Aliyah Negeri 1 Palu Melalui Model Pembelajaran Berbasis Masalah dan Model Pembelajaran Inkuiri. e-Jurnal Mitra Sains. Vol.4, No.2

Saragih, K., and Mardianto. (2019). Relationship between Teacher Professional Performance and Discipline of Workers withTeacher Professionalism in Madrasah Tsanawiyah in Pematangsiantar City. Britain International of Linguistics, Arts and Education (BIoLAE) Journal; 1(2): 77-84.

Sardiman, A.M. 2009. Interaksi dan Motivasi Belajar Mengajar. Jakarta: Rajawali Press

Slavin, R. E. 1997.Educational Psychology Theory and Practice. Fifth Edition. Allyn and Bacon: Boston 
Soedjadi. 2001. "Pembelajaran Matematika Realistik: Pengenalan Awaldan Praktis". Makalah disampaikan pada seminar Nasional di FMIPA UNESA. Semarang: UNESA

Sugiyono. 2011. Metode Penelitian Kuantitatif, Kualitatif, dan R \& D. Bandung: Alfabeta.

Suharta, I. G. P. 2002. PMRI Pengembangan dan Pengimplementasian Prototipe I \& II Topik Pecahan. Jurnal Matematika Tahun VIII. Edisi Khusus. Halaman 451-453. Yogyakarta: USD

Suherman, E, dkk. 2003. Strategi Pembelajaran Matematika Kontemporer. Universitas Pendidikan Indonesia. Bandung : jicA

Suprijono, A. 2011. Cooperative learning Teory dan Aplikasi PAIKEM. Yogyakarta: Pustaka Belajar

Suparno, P. 2001. Filsafat Konstruktivisme dalam Pendidikan. Yogyakarta: Kanisius

Surya, M. 2015. Guru Kreatif dan Inovatif. Handout Mata Kuliah Inovasi Pendidikan.

Susanto, A. 2013. Teori Belajar \& Pembelajaran di SD. Jakarta: Kencana

Tung, K. Y. 2015. Pembelajaran dan Perkembangan Belajar. Jakarta: PT.Indeks

Wijaya, A. 2012. Pendidikan Matematika Realistik. Yogyakarta: Graha Ilmu.

Wijaya, A. 2012. Pendidikan Matematika Realistik Suatu Pendekatan Pembelajaran Matematika. Yogyakarta: Graha Ilmu.

Zulkardi. 2010. How to Design Mathematics Lessons Based on the Realistic. (Online, https//www.reocities.com/ratuilma/rme.html, accessed 17 January 2019) 